\section{Northwestern Ontario}

The Section activities are beginning with the Annual Field Tour. This year's theme is Tree Improvement in Northwestern Ontario. The tour will include demonstrations of plus tree selection techniques, seed orchard design (the good, the bad and the ugly) and grafting techniques. Councilors Roy Klein and Bill Towill are organizing this tour aimed at Lakehead University forestry students and Section Members.

With the start of classes at Lakehead University, Section Members are paired with interested students for the purpose of spending a day together at work. This continues to be a rewarding part of many Section Members' calendars.

Section Member Jack Flowers is representing the Northwestern Ontario Section on a fact finding mission to Bunkpurugu, Ghana. Jack will be assisting other CUSO volunteers in developing an action plan to initiate development projects in this remote area of Ghana. He will be reporting back to Section Members in January of 1989 on his findings.

The Annual Lecture Servies is being finalized with the themes ranging from International Forestry to Class Environmental Assessment.

Paul V. Krabbe Chairman

\section{Vancouver Island}

\section{Gleanings from the Newsletter \\ Section Goals}

The new chairman, Bill Bourgeois, has set the following goals for the Section Council during the comming year:

(1) Public Awareness

Prepare a Vancouver Island Section brochure and develop recommendations for Section activities in public awareness for the next two years.

(2) Public Relations/Media

Develop position papers on major public issues for presentation to media. Respond to issues as they arise and identify events in which the Section should participate to raise forestry's profile in the community.

(3) Elementary Education

Work with the Cowichan Valley School Board to develop an approach to forestry education in elementary schools as a pilot project for expansion into other school districts. Work with the Nanaimo and Duncan School Districts to develop the concept of "school forester".

(4) Membership Training

Develop a program to provide sessions on two or three issues or needs of the membership.

(5) National Forestry Week

Continue high profile program, but with more emphasis in Nanaimo and
Port Alberni.

(6) Fund Raising

Raise $\$ 7000$ through continuation at section fund-raising activities.

(7) Membership

Add 20 new members.

(8) Newsletter

Maintain last year's standard.

These are just the highlights. A busy Section!

\section{Meetings}

The Section held a dinner and dance in Victoria on October 21 as its inaugural meeting for $1988 / 89$, and on November 24 held a panel discussion on the topic "Wise Use of Our Land".

\section{Maritime}

\section{Fall Field Tour}

The 1988 fall field meeting of the Section was held on a sunny Saturday in September. J.D. Irving Ltd. hosted about 20 members and students at their tree improvement facilities in the Sussex area.

Our visit began at the Sussex tree nursery, where we were welcomed by Dave Oxley, JDI Woodlands Manager. The nursery is largely devoted to tree improvement. Seedling seed orchards and progeny tests are grown here. The nursery also has a breeding garden where all clones from the improvement program are represented. Accelerated breeding work is carried out at this complex. The tour ended at the Parkindale seed orchard. This orchard was established to develop genetically improved seed, using grafted stock from plus trees.

A fine barbecue, hosted by JDI, ended the proceedings on an excellent note. Many thanks to Blake Brunsdon and the other JDI staff who spent a Saturday with us explaining their tree improvement program.

(Darrell Kitchen)

\section{CIF Meetings}

The first of this fall's series of CIF informal meetings, organised by Eric Wang, was held at the Hugh John Flemming Forestry Centre in Fredericton.

On this occasion, the former Dean of Forestry, UNB, Dr. Jack Ker spoke on his visit to the People's Republic of China last November and December. Jack led a fourperson mission to evaluate, for the International Development Research Centre, the effectiveness of the forest research aid that Canada has provided for the past six years. In the sixties and seventies, the forests in China were sadly neglected and only within the last decade have attempts been made to rectify this neglect. Jack described, with the aid of a series of coloured slides, some of the research projects now under way.

A number of local CIF members served as judges at the annual UNB Woodsmen's Field Day which was held on campus in mid-October. Once again the sun shone

\title{
Lake of the Woods
}

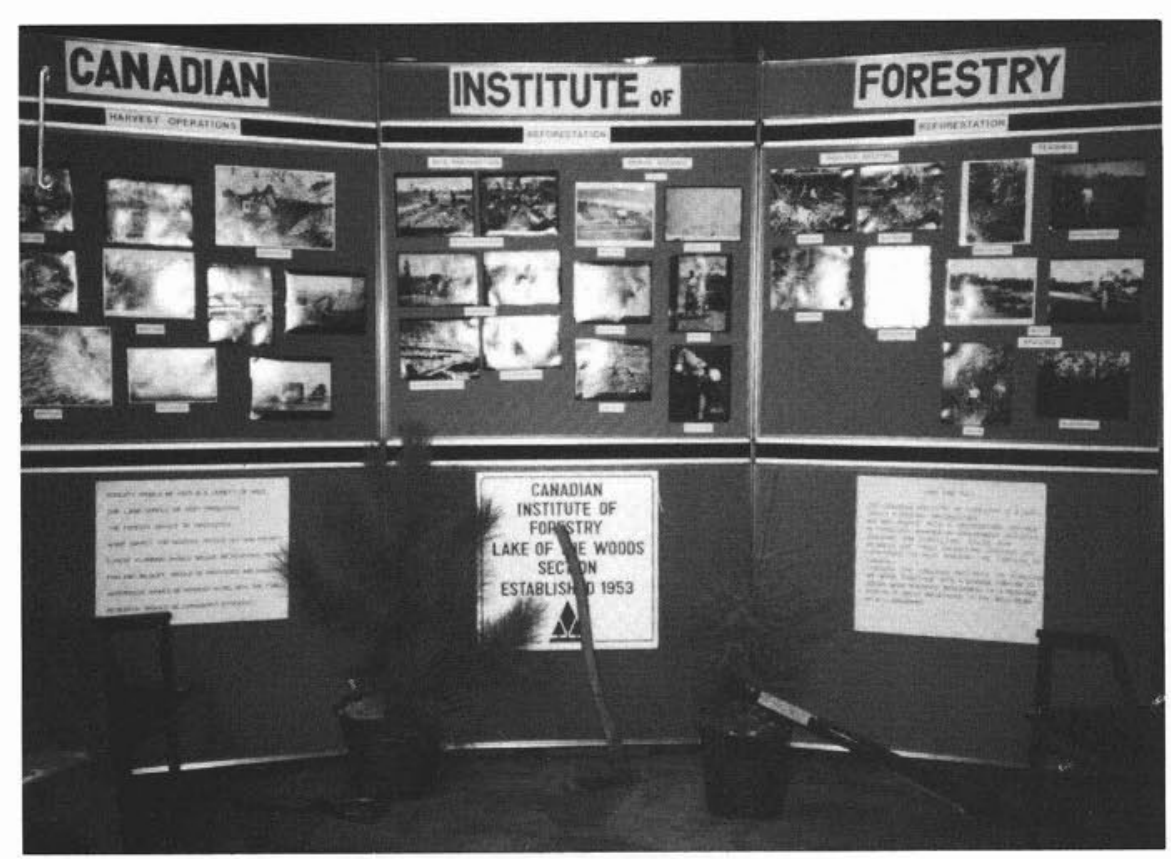

Lake of the Woods display booth at the Emo Fall Fair. 
brilliantly (obviously the organisers live right) and once again the UNB foresters' A team came out on top; their third consecutive victory on home turf. The ladies from Macdonald College captured top honours in their competition.

Early in November we were saddened by the loss, due to a severe wind storm, of one of the Great Trees of New Brunswick. It was a majestic red oak planted, in front of the provincial legislature building, on the occasion of Queen Victoria's birthday in 1900. However, it will live on, or at least parts of it will, as several pieces including a large burl, were acquired by some of the local craftsmen.

\section{Bob Spurway}

\section{Vancouver}

The first dinner meeting of the new year, on September 13, heard a very interesting update on the effects of Free Trade on the Forest Industry. Jim Matkin, President and CEO for the Business Council of British Columbia, gave a brief history of our efforts to establish a free trade agreement (FTA) with the US. He pointed out that Canada had a FTA with the US in 1854, but it was abrogated in 1866 by the American Congress as a punishment for Britain's role in the Civil War. There have been several attempts to reestablish a FTA. There are several advantages to a FTA, not the least of which would be to give Canada access to a market of 243 million people. Mr. Matkin also highlighted the effects of the current tariff structures between our two countries. The fact that tariffs increase as value is added to a product is a great impediment to establishment of our own secondary industries. This is one of the major reasons that we have not added value to our products. A FTA would do away with the tariff books but we were warned that other nontariff barriers would become more important.

The second speaker of the evening was Professor Chris Thomas, member of the Faculty of Law at the University of British Columbia. He was an adviser to the federal government during the Canada-U.S. trade negotiations. Mr. Thomas made the point that both Canada and the United States are members of the General Agreement on Tariffs and Trade (GATT) and that in some contentious issues, Canada has been in violation of GATT rather than with any specific agreement with the US. He cited the "foreign alcoholic beverages" issue where Canada was clearly in contravention of the GATT. It is important that any FTA acknowledges the arrangements that have already been agreed to under GATT. Thus a FTA would be an elaboration of this internationally recognized treaty and both should be considered together. Safeguard clauses, for periods up to 10 years, could be negotiated for areas needing special protection. The mechanics of dispute settlement were also discussed.

The Section members present were certainly made aware of the complexities of the opportunities and problems associated with developing a free trade agreement. We were assured that Canada's advisers had done their research thoroughly and that in most cases they were far better prepared than their US counterparts.

Two of our members were honoured over the summer. Peter Pearse was named a member of the Order of Canada by Governor General Jeanne Sauve on July 14 . John Borden, world renowned insect pheromone researcher, and Professor at Simon Fraser University, was awarded the Entomological Society of Canada's Gold Medal during the July Annual Meeting which was part of the World Congress of Entomology held at UBC

\section{J.A. McLean}

\section{Southern Ontario}

\section{Section Meeting}

By the time this appears in print, the Section will have held a joint meeting with the Foresters' Club of the Faculty of Forestry, University of Toronto. It will feature a panel discussion on the theme "Class Environmental Assessment on Timber Management: An Opportunity to Discuss." Panel members were Julian A. Dunster (Chairman, SOS), I.D. (Joe) Bird, (Executive Director, Ontario Forest Industries Association), John W. Ebbs, (Executive Director, Ontario Professional Foresters Association), Don Huft, (Chairman, Forests for Tomorrow), and a spokesman for the Ontario Ministry of Natural Resources.

\section{Woodlot Management}

Gordon Sinclair is in the process of setting up an SOS group on private land forestry. Several SOS Council members have met with representatives of the Ontario Federation of Agriculture to explore the idea of a common lobby on the management of woodlots.

\section{Algonquin}

\section{Algonquin Section holds Symposium on Forest Research}

On October 3, 4, and 5 the Algonquin Section hosted a symposium titled "Advances in Canadian Forest Research". The meeting is part of an initiative by the Section to produce a special issue of the Canadian Journal of Forest Research, containing state of the art review papers on leading forest research programs. The ten authors came to Petawawa to give 30 minute presentations on the contents of their respective papers. The meeting attracted attendees from the forest industry, the federal and provincial governments and the universities.

The symposium started with an introduction by Jack Wright, current chairman of the Forest Research Advisory Council of Canada, who spoke representing the
Canadian Pulp and Paper Association. A retired chief forester from Champion (Alberta) Ltd., Mr. Wright talked about the needs of industry and the realities of industrial forest management. Dr. Karel Klinka then discussed the current forest site classification program in British Columbia and the new research going on to functionally describe site units. Dr. Nigel Burdett, of the University of Victoria, followed with a discussion of the design of forest planting stock and the process of tree establishment after outplanting. Dr. Hank Margolis of the Université Laval discussed further the process of plantation establishment and growth from an ecophysiological viewpoint. Dr. Brad Kropp, also from the Université Laval, talked about the effect of mycorrhizal symbioses on the early establishment of plantations, and the current inoculation technology available. Drs. Bruce Dancik and Dick Pharis, from the University of Alberta and University of Calgary respectively, closed out the morning session with a description of their work on accelerated testing of improved conifer seedlings and the use of gibberelins for accelerating growth.

After lunch the second session was devoted more to technological developments. Claude Godbout, president of the $\mathrm{CIF}$ chaired the meeting. The first speaker was Dr. Bill Cheliak, of the Petawawa National Forestry Institute, who spoke on the impact of biotechnological solutions on the time taken for tree improvement in forest management and the potential impacts of genetic engineering. Dr. Dave MacLean of the CFS, Maritimes, then outlined his research on estimating growth and yield in the face of uncertainty about fire and insect epidemics. Peter Kourtz, also of PNFI, gave an overview of the artificial intelligence field, and described some of the expert system components available today and their potential use in forestry. Dr. Don Leckie, of PNFI, described the state of the art in remote sensing technology with some impressive satellite and aerial images of color enhancement and tree species identification from digital images. The last presentation was made by Dr. Bob Kellogg of FORINTEK, who discussed the potential changes in wood quality that must be expected based on various management regimes in our current plantation forests.

To wrap up the day, Mr. Jean-Claude Mercier, ADM of the Canadian Forestry Services, polled the researchers and the forest managers about what they had learned and how much of what they had heard could be used to improve the efficiency of forest management. The response by forest managers was encouraging, with most saying that many of the things they had heard were applicable to their problems. During the evening banquet, Dr. Gordon Baskerville discussed forest research in Canada and introduced the concepts of competitive research (designed to make a particular company more efficient than its competitors) and non-competitive research (designed for the public good or the good 
of all operators equally). He indicated that all of the research discussed during the meeting was non-competitive in nature as it was being presented and published in a public forum. Many of the questions left by Dr. Baskerville were pertinent to those of us involved in research, as we must sometimes consider whom we are trying to serve and how.

On the second day of the meeting, several field trips were organized by PNFI researchers to look at new technologies, field genetics experiments, and reforestation trials. The publication of the papers is now in the hands of the Canadian Journal of Forest Research. After peer review and revision, we can expect to publish the papers in mid-summer of 1989. All members of the CIF will receive a copy of that issue free of charge thanks to the sponsorship of the Canadian Forestry Service and the Forestry Awareness in Canada Trust. This special publication should serve as an introduction to the various fields, giving foresters access to the leading edge of these research programs.

Some discussions have been held about staging this symposium as a regular biennial event, with different CIF sections acting as host. Based on the success of the meeting at PNFI, the concept seems worth continuing - any takers for a 1900 version?

\section{Dave Brand}

\section{Rocky Mountain}

\section{Fall Conference Highlights \\ Technical Session}

The 1988-89 program for the Rocky Mountain Section is now full steam ahead. The first Technical Session of the year was held in Whitecourt, Alberta on November 4th and 5th. The session followed the theme "A Forest Industry Strategy for Alberta" and focus for this session was on "Alberta's Forest Industry - The Basics". The panel guests presented to a full house of 112 session attendees, the facts and opinions on how healthy the forest industry is now and will be in the future, how Alberta competes on the global and local scene in terms of various wood products, how technology affects the market place and the growing influence that the public has on the forest industry.

The first speaker, Dr. Mike Percy, Associate Chairman, Department of Economics, University of Alberta, discussed the fundamentals of how the forest industry competes. He advised that the most significant shocks for the industry are those that are domestic shocks which are often induced by federal policy. One of these shocks is the proposed Business Transfer and Consumption Tax which would hit housing prices hard. Dr. Percy also discussed the effects that free trade and other major economic factors will have on the forest industry. He acknowledged that the forest industry has few instabilities compared with other indus-

\section{Nova Scotia}

\section{Fall Field Meeting}

This years fall field meeting was held in Cape Breton on September 7-8. Section Council held a business meeting on the evening of the 7 th

The following morning began with a field trip of a somewhat different nature. $A$ boat was chartered and we proceeded to make our way to a new open-pit dolomitic limestone operation. The next stop was at a trout and salmon aqua-farm located on the shore of the Bras D'or Lakes. Lunch was served on board and our Captain managed to find a hidden harbour which made for a most memorable meal. During the afternoon we sailed to the Bird Islands, the summer breeding location of the puffin. $\mathrm{CIF}$ member, and biologist, Bob Bancroft, ensured that no one missed any of the wildlife features during the day.

Even with the tour focusing on a wildlife theme, the conversation seldom wandered far from the more traditional forestry topics.

Thanks to all who participated and helped organize this meeting.

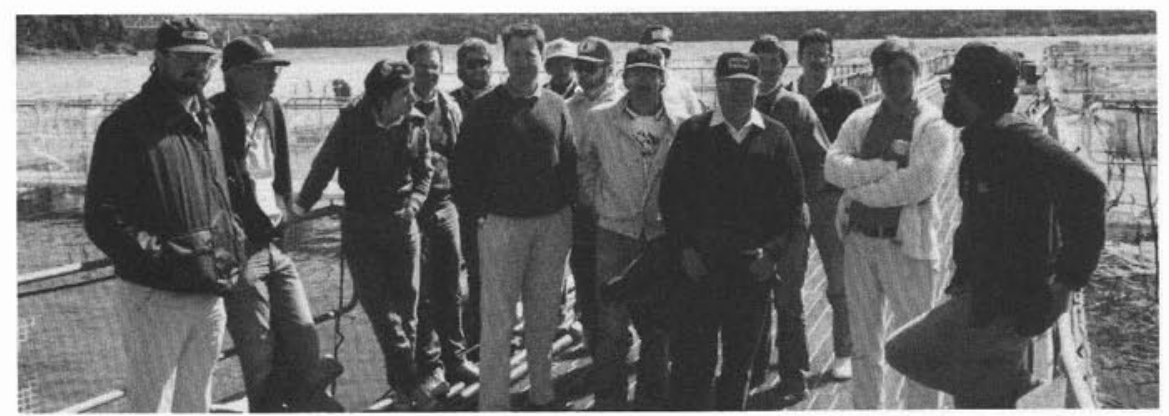

The fall field meeting of the CIF (N.S. Section) included a stop at a high-tech aqua-farm where rainbow trout and Atlantic salmon are raised.

tries in Alberta and how it remained out of phase from other industries, eg. the Energy industry.

Important changes that will affect the forest products sector include market based supply which is influenced by technological change (harvesting, processing) and a change in the nature of the resource base utilized (eg. genetic engineering), an instable institutional environment and transportation deregulation. He concluded that strategically Alberta is sitting very well in terms of diversification and trade between Canada and the States. Transportation deregulation would certainly help our land-locked province, as $35 \%$ of industry's cost is transportation, but the potential for technological change is good in Alberta.

Robert Haglar, president of Wood Resources International, opened his remarks in saying that competition within the forest industry has changed on a global as well as on the local scene. Factors that have lead to this have been: standardization of products, rapid technology transfer, decreased trade barriers efficient transportation systems, and integrated financial matters.

Changing participants and the competitive advantages of the new participants such as fast growing species, and cost have led to very interesting competition on the global scene. Mr. Haglar expounded upon the significant effects that relative fibre supply and relative wood costs have and will have on the market place for the various global participants. He advised that the shooting stars will be Chili and New Zealand while falling stars would be Eastern Canada and the northwestern United States. Those that would remain competitive would include Scandinavia and Alberta and British Columbia, to mention a few. Alberta is in the unique position of being able to supply hardwood to the Pacific, while coniferous wood goes to the East/Atlantic.

Mr. Haglar went on further to explain how Alberta as a regional market compares globally. He emphasized that although Alberta is doing well as a production cost oriented area, one cannot compete on costs alone. Other strategies such as technology and new product sources are necessary. He concluded that Alberta has room for expansion and good market opportunities both east and west regionally, particularly in light of its relatively low wood costs. Alberta should avoid the commodity trap and control costs via patient capital and progressive technology.

Dr. Garrie Styan, vice-president of Woodbridge, Reed and Associates was the third speaker for the afternoon. Dr. Styan took a closer look at the various products and expounded upon their influence on Alberta's forest industry. He advised that it is important that we are changing the ways we are doing or not doing it. In newsprint and market pulp there is a lot of room for growth while lumber depends on the growth/demand and sites. 
Timing is important. He recommended to stay away from linerboard and sack kraft as well as tissue. There are market driven opportunities for panel products.

In any product, quality is key to stay in business in the long run. Dr. Styan concluded that today Alberta is in a better position than even three years ago. This is due to the change in political will and the right wood species that we have come to manage - aspen. But there is room for forest management and improvements to stay ahead in the processing industry.

The last speaker, Jim Vincent, Public Relations Consultant, gave a new perspective on public issue management with respect to the Alberta forest industry. $\mathrm{He}$ opened by stating that most of the public will oppose any corporate decision unless they have had some involvement. Interest groups today are very powerful since they are well planned, well financed and well educated. It is therefore important to consider what the public want and offer it to them, particularly to acquire adequate strategic plans. Before taking any action, look at the results you want and what results are going to take place in view of where public interest lies and how this may affect your goals. It is best to devise some appropriate action to take issues in stride.

A review then was made of the issue management process by Chase and Jones as it relates to the forest industry. Identify the issue, analyze it as it sits currently with past issue experience and identify tactics to deal with it. Mr. Vincent concluded that the impact is that the Alberta forest industry needs to negotiate with interest groups and make the public aware since public view can be steered.

\section{Dinner Speaker/Field Tours}

The excellent banquet was rounded off with Peter Knorr, Vice-President of Millar Western, giving an entertaining talk entitled "CTMP - The Whitecourt Experience". He gave the inside story of how the new Millar Western pulp mill really started as well as giving details on how their CTMP (Chemical Thermal Mechanical Pulp) Mill will differ from the regular kraft mill. He also discussed their new strategy in employee management, basing pay not on job responsibilities but rather on employee expertise and skill.

Two interesting tours were arranged for on the second day of the program. The Industrial Tour included tours of both the Millar Western Pulp Ltd's new CTMP pulpmill and Blue Ridge Lumber Ltd's medium density fibreboard mill. The Forestry Tour involved a tour of the new Huestis Demonstration Forest which provided examples of the many different technologies in site treatment and reforestation.

\section{Future Sessions For 1988-89}

There will be three more sessions for this program year. Two sessions will be looking further at the Forest Strategy theme, while the third session is still in planning. The sessions will take place in Rocky Mountain House on January 20 and 21. Edmonton on March 17, and Grande Prairie on May 12 and 13, 1989. We encourage $\mathrm{ClF}$ members from other provinces to attend these sessions.

The Rocky Mountain Section's intends to make these meetings as productive as possible. Over the summer the Section has continued to pressure the provincial government to develop a strategic plan for the forest sector in Alberta. These efforts have met with little success. Given the increasing importance of forestry in Alberta and the high level of development that is occurring in this sector, we feel that it is imperative that a strategic plan is in place. This is the primary reason for deciding on strategic planning as a theme for the technical sessions this year.

\section{8-89 Program Sessions}

The program committee is full steam ahead with the first Technical Session of the year for the Rocky Mountain Section to be held in Whitecourt, Alberta on October 14 and 15,1988 . The session will follow the theme of "A Forest Industry Strategy for Alberta" and focus for this session on "Inside Alberta's Forest Industry - The Basics",

Three more sessions will be looking at this Forest Strategy theme. They will be in Rocky Mountain House on January 20 and
21, 1989, Edmonton on March 17, 1989 and Grande Prairie on May 12 and 13. 1989. We would encourage CIF members from other provinces to attend these inevitably most interesting sessions.

It is the Rocky Mountain Section's intent to make these meetings as productive as possible. The Section has been corresponding with Alberta's Forestry Minister, Leroy Fjordbotten, regarding the topic of a provincial forest strategy in light of the National Forest Strategy theme. To date we have not been successful in prompting the Crown to respond positively to jointly formulating a well thought out forest sector strategy for Alberta.

This year's program we feel will make it clear that we are serious about Forest Sector Strategy development in Alberta. We hope that we shall be able to have the Minister attend our technical session in Edmonton in the spring.

\section{New Promotional Items for RMS}

Rocky Mountain Section has just commenced sales on two new promotional items that will certainly be close to the hearts of section CIF members. As well, the new hats and shirts will be a winner with $\mathrm{CIF}$ members across Canada for traders or collectors.

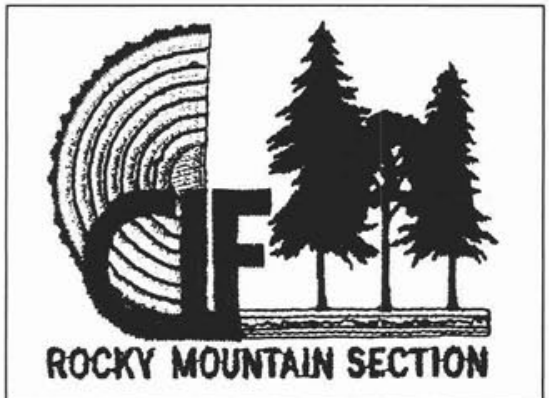

The new ensignia shown above has woven in its design the colors green, brown and gold. Look for these at RMS meetings over the year and at HAMPCO '89.

Margarete J. Hee

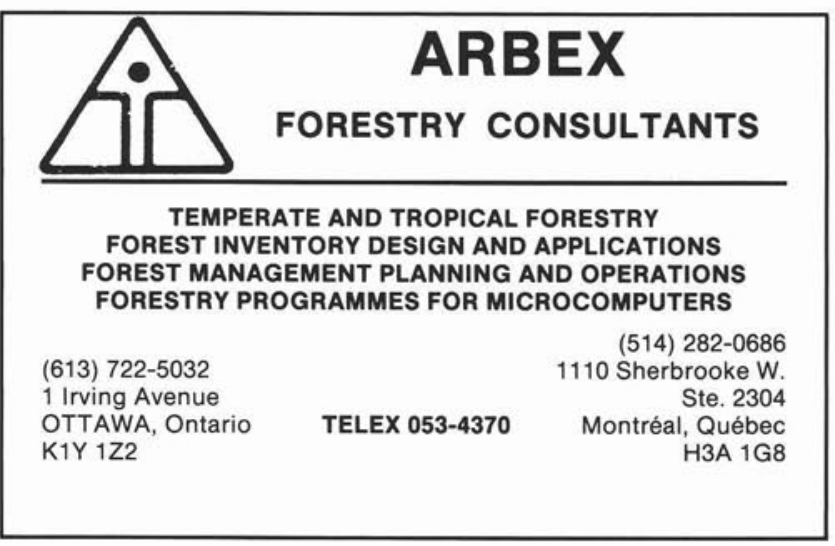

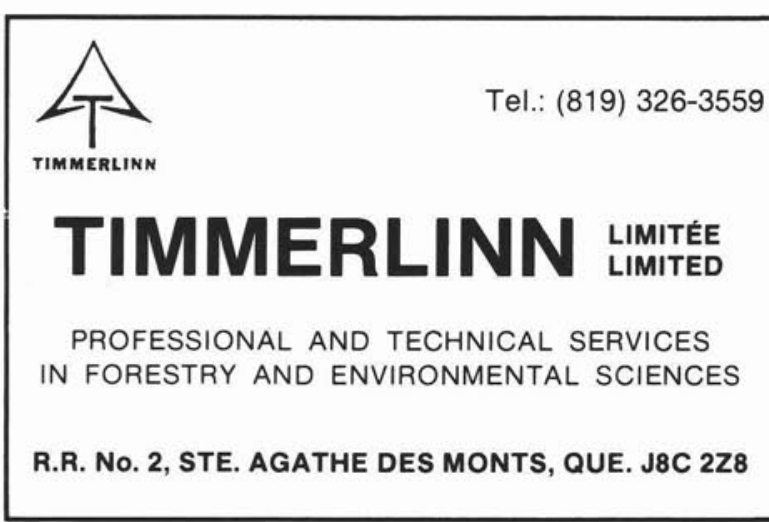

